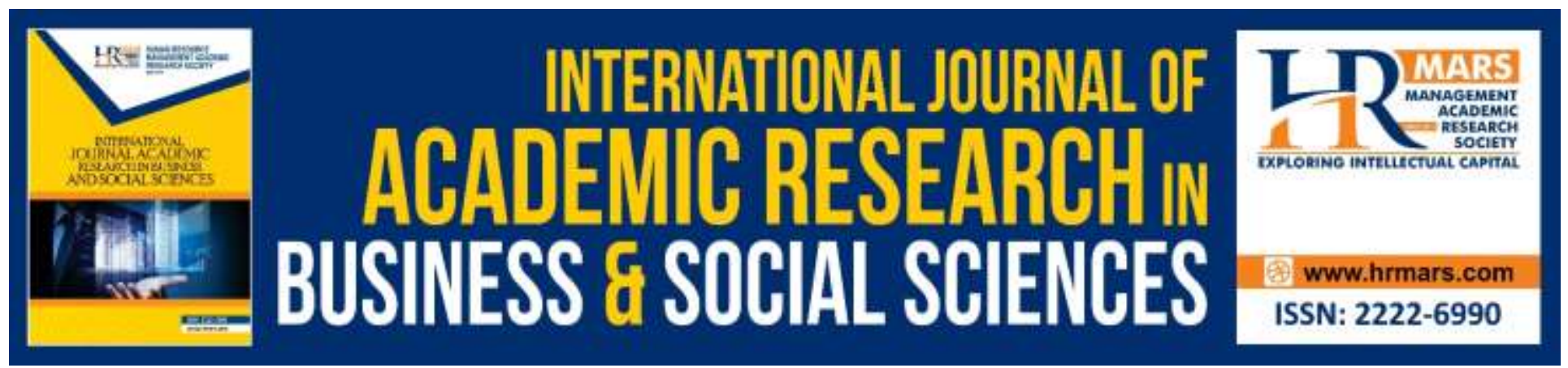

\title{
Human Resource Management Practices from Islamic Perspective: A Study on Bangladesh Context
}

\author{
Md Suliman Hossin, Idris Ali, Ilham Sentosa
}

To Link this Article: http://dx.doi.org/10.6007/IJARBSS/v10-i6/7310

DOI:10.6007/IJARBSS/v10-i6/7310

Received: 20 April 2020, Revised: 26 May 2020, Accepted: 10 June 2020

Published Online: 22 June 2020

In-Text Citation: (Hossin et al., 2020)

To Cite this Article: Hossin, M. S., Ali, I., \& Sentosa, I. (2020). Human Resource Management Practices from Islamic Perspective; A Study on Bangladesh Context. International Journal of Academic Research in Business and Social Sciences, 10(6), 391-405.

Copyright: @ 2020 The Author(s)

Published by Human Resource Management Academic Research Society (www.hrmars.com)

This article is published under the Creative Commons Attribution (CC BY 4.0) license. Anyone may reproduce, distribute, translate and create derivative works of this article (for both commercial and non-commercial purposes), subject to full attribution to the original publication and authors. The full terms of this license may be seen

at: http://creativecommons.org/licences/by/4.0/legalcode

Vol. 10, No. 6, 2020, Pg. 391 - 405

http://hrmars.com/index.php/pages/detail/IJARBSS

JOURNAL HOMEPAGE

Full Terms \& Conditions of access and use can be found at http://hrmars.com/index.php/pages/detail/publication-ethics 


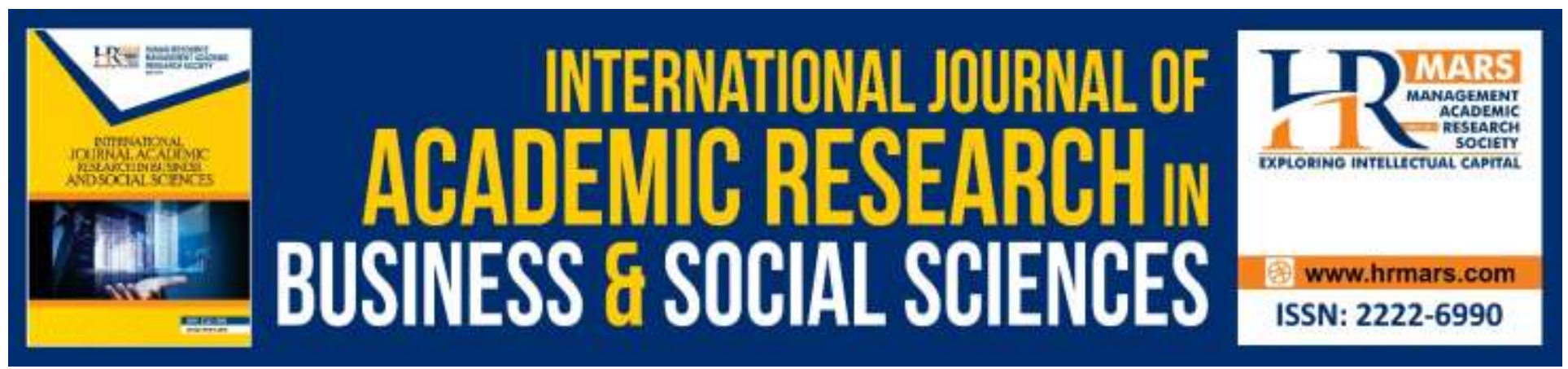

\title{
Human Resource Management Practices from Islamic Perspective: A Study on Bangladesh Context
}

\author{
Md Suliman Hossin ${ }^{1}$, Idris Ali ${ }^{2}$, Ilham Sentosa ${ }^{3}$ \\ PhD Candidate ${ }^{1}$, PhD Student ${ }^{2}$, Associate Professor ${ }^{3}$, UniKL Business School ${ }^{1,3}$, Kulliyyah of \\ Education ${ }^{2}$, University Kuala Lumpur ${ }^{1,3}$, International Islamic University Malaysia ${ }^{2}$ Kuala Lumpur, \\ Malaysia \\ Email: md.suliman@s.unikl.edu.my
}

\section{Abstract}

Purpose: The purpose of the paper is to review and discuss the role of Islamic Human Resources Management (IHRM) practices and the principles of the IHRM system and its necessity in the context of the emerging Islamic banking sector, namely Bangladesh.

Design/Methodology/Approach: This paper highlighted and discussed the importance of Islamic human resource management practices in Bangladesh in addition to a brief discussion on all HRM practices. Nonetheless, this study is based on secondary documents and data obtained from a variety of articles, books, newspapers, journals, and websites.

Findings: It is found in this research that there may be nine IHRM system principles that can positively influence four major IHRM systems, including recruitment and selection, training and development, performance evaluation, and pay and compensation. If all four activities are carried out in accordance with Islamic principles, so the long-term organization can be maintained, and the growth of human capital will be assured.

Originality/value: Explore the key IHRM values of the Al Quran and the rising need for the IHRM system in Bangladesh. Thus, the findings of the study may help to formulate the policies and implement the IHRM program in the Islamic banks.

Keywords: HRM Practices, Islamic Principles, Perspective, Al Quran and Bangladesh.

\section{Introduction}

Human resource management is a key factor in maintaining institutions in the business and maintaining sustainability and productivity for long periods of time in the current hypercompetitive period. Humans have become one of the most important factors in the aggressive marketplace of today, as Kamrujjaman, Al Mamun, \& Akter (2014) said. Managing human resources is one of the main armors, for the most employee - oriented production companies, to keep companies in operation and competitors alive (Mutasim, Ab, Shahid \& Alam, 2011). In brief, we therefore need appropriate HRM practices in order to meet the organizational goal and ensure organizational development. HRM has a vital role in every organization to enable the best use of resources to attain 
INTERNATIONAL JOURNAL OF ACADEMIC RESEARCH IN BUSINESS AND SOCIAL SCIENCES Vol. 10, No. 6, June, 2020, E-ISSN: 2222-6990 @ 2020 HRMARS

organizational and individual goals, Chowdhury, Hoque and Mawla (2012). Though modern HRM practices play a key operational role in the organization again, therefore large companies are often confronted with high - level decisions on the management of protests, even in some cases with high turnover. Bangladesh is largely a Muslim - majority country with $89 \%$ Muslim population, but again the concept is highly new and rarely practiced in the field of Islamic human resource management. As the modern form of HRM practices in some places is becoming controversial, Islamic practices in the management of human resources may be more permissible and biased.

\section{Practices of Human Resource Management in Bangladesh}

The practices of modern human resource management in Bangladesh are not new. Even though modern Human resource practices are widely known across all sorts of businesses organizations, few business sectors are not prepared to accept the latest HRM practices. However, modern HRM practices are very popular all over the world to achieve organizational goals and objectives and human capital development. Aktar \& Pangil, (2018); Kamrujjaman, Al Mamun, \& Akter, (2014 ) indicated that, in order to achieve organizational objectives, organizations should effectively manage their human capital by implementing an effective human resource management process. Moreover, due to lack of effective HRM practices, employees' dissatisfaction with their organization leads to low performance and productivity. As modern HRM practices are not free of bias, and Bangladesh is a Muslim-populated country, Islamic human resource management practices will be the most acceptable and effective way for any organization to achieve its strategic goals and human resource development. In Bangladesh, Islamic banking, insurance and microfinance companies operate their business in accordance with Sharia law, but these firms practice western HR policies and practices. In most cases, these practices contradict the law of Sharia law. In addition, Mutasim et al. (2011) mentioned that Islamic HRM practices are essential but are hardly ever emphasized in the literature. Not only that, because of the lack of Islamic guidance on HRM, is one of the major constraints to the practice of Islamic HRM in a Muslim majority country like Bangladesh.

\section{Methodology}

This study starts with an initial discussion with the Islamic perspective on the general HRM practices. The academic papers, standard works, as well as relevant literature in human resource management domains, practices Islamic human resource management, as well as Islamic principles, are being reviewed. To validate the pertinence of the articles, this study was verified by the journal's overall score published on the Science and Scopus website. The list of identified articles has been sent to the experts in Islamic Human Resource Management to ensure that they are appropriate for our review. Besides, this study was also carried out in an unstructured search by EBSCOhost, Google Scholar, Science Direct, Emerald, Springer Link, JSTOR, University Library world cat, and ProQuest for the available literature with the same keywords. The inclusion criteria have been set out in this study. In connection with this current research, there are only articles relevant to human resource management activities from an Islamic perspective. For this review, as many as a hundred potentially essential articles have been collected for abstract screening. 
INTERNATIONAL JOURNAL OF ACADEMIC RESEARCH IN BUSINESS AND SOCIAL SCIENCES

Vol. 10, No. 6, June, 2020, E-ISSN: 2222-6990 @ 2020 HRMARS

\section{Literature Review}

\section{The Practice of Human Resource Management from Islamic Point of View}

Human resource management (HRM) refers to the process of ensuring, developing, inspiring and supporting human assets (Hashim, 2010b). However, Islamic human resource management (IHRM) is based on acting in the interests of all people in a particular society, focusing on individual behaviour and it also affects the operation or practice of management, because the values and belief systems of individuals performing these roles are composed of Islamic ideology (Ababneh, 2016). Islamic HRM proposes that representatives are not only a hireling, but they also are significant resources, and they ought to be considered as a wellspring of amazing and dynamic workforce resources, and it rehearses accentuations on the improvement of worker's individual aptitudes, capacities, perspectives and occupation information to contribute for achieving authoritative goals (Mutasim et al., 2013). Human resource management is an important procedure that can monitor the human capital's ability to form associations (Rumbley, Van't Land, \& Becker, 2018). The character and morality of Islam influence the management of human resources (Gadelrab et al., 2020).

For Muslim leaders and representatives, the rehearsal of senior executives is undoubtedly clearly influenced by the strict beliefs and guidelines from the Holy Qur'an (the Islamic Scripture) and the Holy Sunnah (Prophet Muhammad said, did or conducted) as Allah mentioned in Quran (59:7) “... and whatsoever the Messenger (Prophet Muhammad PBUH) gives you take it and whatever he forbids you, abstain from it ..." (Branine \& Pollard, 2010). Monitoring human assets in Islamic perspective solves different difficulties (Hashim, 2010a). Cropanzano et al., (2001) have recognized the difficulties that constitute human resource management practices and these practices include culture, legal framework, innovation, hierarchical structure and scale. The Islamic Value Framework provides information and practice for building a comprehensive approach to deal with human resources management (Sarfraz, Qun, Abdullah, \& Alvi, 2018). The IHRM provides some innovative methods to deal with any situation. The leaders or managers can have multiple options to lead and influence their associates, partners, customers, workers and other stakeholders (Abbasi, Rehman, \& Bibi, 2010). The IHRM plays important and significant roles for organizations to gain competitiveness (Umphress, Labianca, Brass, Kass, \& Scholten, 2003).

Adeel et al. (2018) discovered the positive link between Islamic principles and human resources management. This includes the practice of the association to practice Islamic values to monitor human assets. The supervision of human assets in Islamic methodology affects authoritative judges (Jung \& Ali, 2017). In order to gain trust, promising people must be trustworthy and reliable. Allah said: "Everyone swears by the money he earns." In order to seek someone's greatness, Islam urges individuals to unite to find something perfect. Allah said in the Quran: (17:7) "... if you do well, you do well for yourself and if you do sin, you do it to yourself". "You (humans) have not shown any demonstrations, but we are observing When you are locked firmly, "the Prophet Muhammad (SWT) said:" Allah prefers when someone does anything, they must do very well." (Kim \& Park, 2017, and Greenberg, 1987). 
INTERNATIONAL JOURNAL OF ACADEMIC RESEARCH IN BUSINESS AND SOCIAL SCIENCES

Vol. 10, No. 6, June, 2020, E-ISSN: 2222-6990 @ 2020 HRMARS

\section{Major Principles and Values of an Islamic Human Resource Management System}

The basic standards of the Islamic administrative framework have had a huge impact on the behavior of Human Resources management, as follows.

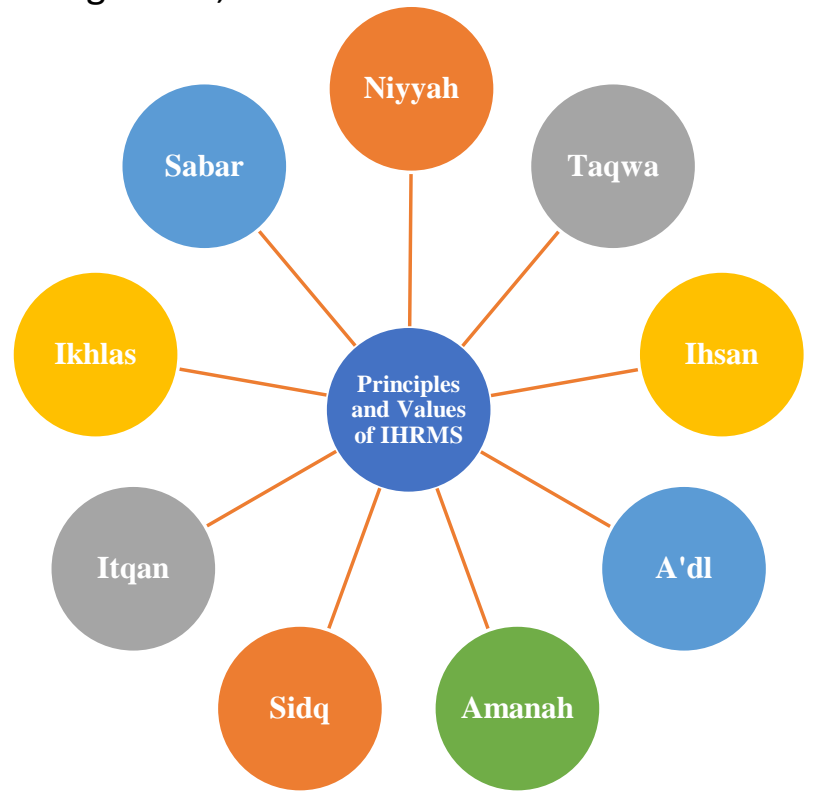

Figure 1: Principles and Values of an Islamic Human Resource Management System (IHRMS)

\section{Intention (NIYYAH)}

In Islam, every action should have a goal (Sulaiman, 2018). The Prophet Muhammad said: "The activity is recorded according to the goal, and the individual will receive the same compensation or rejection" (Helen McLaren 1, 2020). A person will always enjoy freedom and have the responsibility to change the public's perspective. The Qur'an (chapter 13, verse 11) states: "God will not change the state of a country unless it changes something in it" (Majid, Zainol, Daud, Rashid, \& Afthanorhan, 2018). The implementations of this rules on the HRM is that the workers should not be punished for making mistakes unwillingly and should be paid or rejected for the goals, ideas, plans and procedures of its goal, not just for the results of its work activities that are not controlled by external components (Ruzicka, 2018; Barnett et al., 2020).

\section{Forever mindful of the Almighty God (TAQWA)}

Taqwa means to be conscious of the existence of Allah, acting toward pleasing Allah, fear Allah and seek protection from the anger of Allah and His punishment (Mohd. Sidek et al., 2017). In the IHRM perspective, when people own Taqwa, it is easy to take ethical behaviours in homes and workplaces. (Mushtaq \& Khan, 2018; Kamil, N. M. et al.,2010).

\section{Kindness and treatment while feeling the presence of God (IHSAN)}

In the Islamic point of view, Al-Ihsan means kindness or goodness (Sadiq, Mokhtar, Sadiq, \& Mokhtar, 2018). However, It implies a believer's demonstration of love, and he firmly believes that Allah exists, and watching the act of worship (Kadhim, Ahmad, \& Ahmad, 2018). Islam requires relatives to help each other and meet their needs. Therefore, the concept of Ihasan has great significance in the field of human resources management. As Quran says in surah Al-kahf (13:30); those who have faith in 
and work morality, verily We shall not suffer to perish the reward of any who do a [single] righteous deed" (Mohamed, Sultan, Abidin, Shaladdin, \& Abdullah, 2014). The meaning of the above verse is not only related to the goodness, virtue, and generosity but also to rights and fairness of employers and workers in the HRM in Islamic viewpoint (Majeed \& Zanib, 2016).

\section{Justice ( $\left.A^{\prime} d \mathrm{~d}\right)$}

Fairness is a moral concept that everyone should develop, whether he/she is a leader or a subordinate (K. Khan, Abbas, Gul, \& Raja, 2013). The Qur'an says in surah Maida (5:8); “Oh, who believe! Stand out firmly for Allah as a witness to fair management and dot not hatred of others to you make you swerve to wrong and abstain from fairness". Justice can also ensure individual opportunity and unity (Loi, Hang-yue, \& Foley, 2006). In Islam, people have freedom in their beliefs, the Quran mentioned in surah Baqarah (2:256); "There is no religious impulse". "All individuals are equally indifferent to gender, colour, race, wealth, prestige, profession, status, and knowledge. The real counts are their activities and behaviours (Betts, Setterstrom, Pearson, \& Totty, 2014). The Prophet Mohammed stated that individuals are equal as he said: 'An Arab has no preference over a non-Arab, nor a non-Arab over an Arab, nor is a white one to be preferred to a black one, nor a black one to a white one, except in piety - righteousness (Tirmiji) (Rokhman \& Hassan, 2012). In any organizations where fairness and justice prevail, the workers are treated and paid fairly and equally, especially in human resource management in the Islamic perspective (Fischer \& Smith, 2006). Therefore, managers and employers will treat their subordinates with humility and politeness and never underestimate them or ignore their views and suggestions (Rokhman \& Hassan, 2012).

\section{Trust (AMANAH)}

The concept of trust is the basic belief in managing authority connections because everyone is considered responsible for their actions in the organization, especially in the field of human resource management (Jusoh \& Ibrahim, 2018). The Qur'an says in surah A'raf (8:27): “O you who believe! Betray not Allah and His prophet, not betray knowingly your Amana (things entrusted to you, and all the duties which Allah has ordained for you) (Hazween et al., 2019). In light of the above verse, trust is the fundamental issue, which inculcates trustworthiness in both the managers and workers in the human resource management practice (Hasmiene et al., 2018). At the same time, the leader or manager is an "Ameen" or trustee, and his or her superiors and subordinates should trust him/her (Islam \& Samsudin, 2018).Therefore, any misuse of assets or mismanagement is considered an infringement of trust. The association is the trust of the individuals who own it and the individuals who work in it, especially in the human resources management organizations in Islamic viewpoint (Erihadiana, 2019 Ahmad et al., 2017).

\section{Truthfulness (SIDQ)}

The philosophy of Sidq or truthfulness refers to do and say what is correct and lawful. However, Islam prohibits lying or cheating under any circumstances (Erdil, 2016). There are many sections in the Qur'an that emphasize moral and honest evaluation. As Allah said in the Qur'an, Taoba (9: 119); "O you who believe! Fear Allah, and being with truthful people". The Qur'an also says in the Qur'an (Ahzab) (33:70); "O you who believe! Fear Allah and talk about proper fair expression" (M. Hashim, 2012). As pointed out from the Qur'anic verse which mentioned above, just like reminding subordinates and managers should not use their sentiments as a guide, which may cause them to 
deviate from the correct way of fairness, care and reliability (Rahman, 2010). In this way, executives and subordinates, while seeking the worship and kindness of God, show restraint, fulfil their legally binding obligations and are completely straightforward and submissive (Ebrahimi \& Yusoff, 2017). Therefore, the managers and subordinates are highly required to be honest and to work hard, while searching Allah's blessings and mercy. Subsequently, in the view of the IHRM, authenticity and reliability are essential for feasible management (Nuriman \& Fauzan, 2017).

\section{Conscientious of self-improvement (Itqan)}

This concept refers to a constant struggle for self-improvement within oneself in order to accomplish better work (Isgandarova, 2019). However, the expectation of continuous improvement is that people work harder by learning new information and abilities, and improve the nature of their projects and administration (Sadeghi-boroujerdi, 2006; Khan Shahid et al.,2018). In terms of human assets, executives are constantly striving to improve their qualities, requiring directors and representatives to work more actively, and improve the nature of their projects and administrative management through innovation, preparation, development, and creative progress (Sa'ari \& Harun, 2018).

\section{Sincerity and keeping promises (Ikhlas)}

Compliance is the moral commitment of every Muslim (Salleh, 2015). It is a sin to deliberately ignore one's promise, and breaking one's word is not allowed in Islam. Islam characterized a person as a hypocrite who fails to meet one's commitment intentionally. Islam also emphasizes to fulfil one's promise as Allah said in the Quran in surah Maida (5:1); "O you who believe! Fulfil (all) obligations..." (Cruz, 2013). Keeping promise and sincerity, therefore, inculcate trust and authenticity in any organizations and provide trustworthiness and collaboration between managers and workers basically in terms of human resource management practice (Monjur, 2015; Alimin et al., 2018).

\section{Consultation (Shura)}

The best way to make the decision about worldly affairs in the absence of Quranic text and hadith is called consultation or Shura (Mohamad Yunus, 2018). Islam emphasized that, in collective issues, all decisions should be made through meetings and consultations (Bartlett, Longo, Puzhko, Gagnon, \& Rahimzadeh, 2018). In the practice of Islamic human resource management, the managers or supervisor must seek guidance and consult others before making a decision. As the Quran says addressing the believers in surah shura (42:38); "their matters are shura among them..." (Sheikh \& Bhatti, 2017). The concept of Shura guides the managers and leaders properly to treat their workers and followers equally and being humble in their coping with other people (Alade, Muhammad Nasri, \& Ahmad Bashir, 2016). Therefore, the managers and leaders in any organizations are highly required to make any decisions or conduct their affairs by mutual consultation, especially in human resource management practice (Ogunbado \& Ahmed, 2019).

\section{Patience (Sabar)}

Tolerance is the highest state of Iman (full of confidence in the unity of God, and Muhammad is his prophet and messenger) (Saritoprak, Exline, \& Stauner, 2018). In HRM perspective, tolerance and quietness are inseparable. Showing restraint in choice will reduce the chance of making mistakes and expand the chance of success of the management, especially in the practice of human resource 
INTERNATIONAL JOURNAL OF ACADEMIC RESEARCH IN BUSINESS AND SOCIAL SCIENCES Vol. 10, No. 6, June, 2020, E-ISSN: 2222-6990 @ 2020 HRMARS

management fields (Mohamed-Saleem, 2016). There is much verse in Quran emphasized people to be patient and quiet in their daily affairs, and it is the key way to success in this worldly life especially in HMR management practice and the life after death as well. As the Quran says in Surah Al-Imran (3:200); "O you who have believed, endure and survive and remain stationed and fear Allah that you may be successful". The Quran also stated in surah Baqarah (2:153) that Allah always with those people who are patient "O you who have believed, seek help through patience and prayer. Indeed, Allah is with the patient" (Rusdi \& Indonesia, 2017.; Achour et al., 2015b).

Therefore, in any organizations where IHRMS is practiced, the managers, employers and subordinates should be very patient in dealing with their respective affairs in their work, especially in core areas of HRM practices.

\section{Practices of Islamic Human Resource Management (PIHRM) \\ Recruitment and Selection}

Enlistment is the process of selecting potential competitors for the association to take advantage (Crowley-henry \& Ariss, 2018). From the perspective of IHRM, the determination is to choose the right personal strategy, which will affect the trust and dedication to the association. If the candidates are elected in order of favouritism and not because of his ability, generally speaking, people will feel sceptical and unfaithful (Abbazi \& Zarqan, 2019). Al-Quran provides a very simple but very relevant criterion for selecting the best applicant. As the Qur'an says in Surah Al-Qasas; (28:26); "O my (dear) father! Engage him on wages truly the best of men for you to employ is the (man) is strong and trusty". (Ghernaout, 2017). The Qur'an also mentioned another set of standards, namely Accountability and skills required to handle specific jobs. As Allah said in surah Yusuf (12:55); "As I know, placing me on the warehouse of this land, I do Will guard them" (Corri Zoli*, 2017). In order to ensure the selection of the ideal individual, the Islamic method should be considered to select the best attributes of the applicant (Ghernaout, 2017). In addition, IHRM's approach does not allow recruitment to be biased because it abuses fair, ethical standards and enters into agreements with companies to take care of the enthusiasm of the association and the privileges of others in transactions. As the Qur'an says in surah An-Nahl (16:90); "Allah ordered fairness and doing good to friends and family. He forbids every shameful behaviour, unfairness and resistance" (Hunter, Shortland, Crayne, Ligon, \& Samuel, 2017).

\section{Training and Development}

The organization should urge its representatives to add additional capabilities and information through preparation and promotion plans (Wang \& Wart, 2007). It improves representative efficiency and encourages workers to have better career opportunities (Ayentimi, Burgess, \& Brown, 2018). The Islamic ethical framework makes information mandatory for everyone. This information implies not only basic Islamic information but also has mandatory information and expertise, which is very important to complete the agreement with their manager (Burke-smalley \& Hutchins, 2014; Tarique \& Caligiuri, 2009). Subsequently, Islam emphasized the dual characteristics of the labour force, moral qualities and professional qualities (Bhatti, 2014) Budhwar \& Pereira, 2019). Thus, nowadays, organizations are focusing on investing in employee development through internal and external training. 
INTERNATIONAL JOURNAL OF ACADEMIC RESEARCH IN BUSINESS AND SOCIAL SCIENCES

Vol. 10, No. 6, June, 2020, E-ISSN: 2222-6990 @ 2020 HRMARS

\section{Performance Appraisal}

Perform inspections in HRM refers to evaluate the performance of a person's activities. If this is not feasible, it will lead to a decrease in efficiency and may cause dissatisfaction (Kadiresan et al., 2015). In order to avoid this situation, representatives who work effectively should be compensated appropriately, which will make them feel necessary and become an important part of the association (Glaister, Tatoglu, \& Karacay, 2018). Individuals with poor performance should be informed so that they may work more actively to achieve their goals (Dysvik, 2010). Improper use of inspections is not only demoralizing, but it is also dishonest. A biased assessment violates the ethical principles of justice and fairness, people's rights, and is not part of the Islamic system. As the Prophet (PBUH) has forbidden to involve any unethical practices and he said; "Whoever cheats is not from me" - Muslim, (M. Rahman, 2016) Some investigations support the idea that the reasonableness of performing inspections and the workers 'responsibilities to their associations have been firmly established (Hashim, 2009).

\section{Compensation and Wages}

From an HRM practice perspective, Islam urges managers to compensate their representatives or employees based on their capabilities, encounters, information, capabilities, and work did (Alvaredo, Atkinson, Piketty, \& Saez, 2013). However, companies should avoid any preference, tendency, or prejudice. Their goal is to allow them to recognize workers with fair and considerable compensation. As Allah said in Surah A'raf (7:85); "... So provide full measure and full weight and don't make mistakes in human things ..." (Adachi, 2018). The Islamic Human Resources Department requires senior executives to practice that the salary level should be sufficient to meet the needs of employees, such as the purchase of nutrition, clothing, ready-made accommodation, and the typical costs of basic items with special consideration of the main standards / regulated transportation conditions (Quttainah \& Almutairi, 2017). Regardless of the gender orientation of the experts, there is no difference in compensation workers (Surah a Nahl; 16:97, Surah al-Kahfi; 18:30) (Doktoralina, 2016). At the same time, Employers should also practice that the wages should be paid immediately after the employees complete their work because the Holy Prophet (PBUH) said: "Pay the wages to the worker before dries his sweating." He also said that they should be paid immediately after the work Reward (Sunan Ibn Magja), Anas (RA) pointed out that the Prophet (PBUH) never paid anyone low wages (Khattab, 2016). It is also mentioned in the Hadith: "One of the three people with whom the Prophet (PBUH) will contend on Judgment Day is a person who keeps in touch with the worker and appreciates all his profits, but he does not pay his due compensation" (Uddin, lqbal, \& Hoque, 2014). In Islam, delay paying the workers or employees is not allowed, because this is unfair and cruel. Those companies that do not pay their workers on time are disobeying rules of the Holy Prophet and Allah (SWT) (Sunan Buhari, Surahed: 85; Surah Alav: 85; Surah Meida: 8) (Haji-Othman \& Fisol, 2017). In addition, according to Islamic principles of ethics in human resource management, Allah cursed those people who are not paying the compensation of their employees fairly. As Quran mentioned in surah Al-Mutaffifin (83:1-3); "Woe to those who deal in fraud, those who take the full measure when they receive from others, but give less when giving them in measure or weight" \{Formatting Citation\}.

\section{Conclusion}

People in the west have developed modern HRM methods from an approach that can apply from their point of view, but Muslims are seeking to adopt real-life examples of Prophet Mohammed SAW 
INTERNATIONAL JOURNAL OF ACADEMIC RESEARCH IN BUSINESS AND SOCIAL SCIENCES Vol. 10, No. 6, June, 2020, E-ISSN: 2222-6990 @ 2020 HRMARS

(PBUH) and the teaching of the Quran that uses the Islamic Human Resources Management System (IHRMS). However, as Bangladesh is a Muslim-majority developing country, Islamic business organizations, NGOs, banks and foundations are rising quite rapidly; hence the importance of IHRM practices is also increasing. If the organization implements policies in compliance with Islamic principles, employee dissatisfaction will be reduced, productivity will increase, and the overall competitiveness of the organization will increase through the general discussion of IHRM practices in this article. However, future studies on this given topic can be undertaken by collecting data from the Islamic Financial Institutes.

\section{References}

Ababneh, H. T. (2016). Impact of Islamic values on HRM practices : an empirical study of Jordanian universities Alex Avramenko. Int. J. Business Excellence, 10(1), 1-19.

Abbasi, A. S., Rehman, K. U., \& Bibi, A. (2010). Islamic management model. African Journal of Business Management, 4(9), 1873-1882.

Abbazi, U., \& Zarqan, I. A. (2019). Islamic Pedagogy on Human Resource Management based on Islamic References. ... of Islamic Business and Economic ..., 2(1), 1-9.

Achour, M., Bensaid, B., Roslan, M., \& Mohd, B. (2015). An Islamic Perspective on Coping with Life Stressors An Islamic Perspective on Coping with Life Stressors. Research Gate, O(January), 124. https://doi.org/10.1007/s11482-015-9389-8

Adachi, M. (2018). Discourses of Institutionalization of Zakat Management System in Contemporary Indonesia : Effect of the Revitalization of Islamic Economics. International Journal of Zakat, 3(1), 23-35.

Adeel, M. M., Khan, H. G. A., Zafar, N., \& Rizvi, S. T. (2018). Passive leadership and its relationship with organizational justice: Verifying mediating role of affect-based trust. Journal of Management Development, 37(2), 212-223. https://doi.org/10.1108/JMD-05-2017-0187

Ahmad, K., Majid, R. A., Abdullah, Z., Minhad, S. F. N., \& Shafinar, I. (2017). Acceptance of Hibah as an Alternative Mechanism in Muslims Asset Management. SHS Web of Conferences, 36(0), 1-9. https://doi.org/10.1051/shsconf/20173600030

Aktar, A., \& Pangil, F. (2018). Mediating role of organizational commitment in the relationship between human resource management practices and employee engagement: Does black box stage exist? In International Journal of Sociology and Social Policy (Vol. 38). https://doi.org/10.1108/IJSSP-08-2017-0097

Alade, T. E. A., Nasri, M. H., \& Bashir, A. (2016). Islamic leadership principles on mosque performance in Lagos State, Nigeria. International Journal of Islamic Business (IJIB), 1(2), 119.

Alimin, N. S. N. B., Awang, S. R. B., Ahmad, T., Safar, J., \& Nain, S. M. (2018). Trustworthiness: The Core of Leadership in Islam. SHS Web of Conferences, 56(0), 1-9. https://doi.org/10.1051/shsconf/20185603002

Alvaredo, F., Atkinson, A. B., Piketty, T., \& Saez, E. (2013). The top 1 percent in international and historical perspective. Journal of Economic Perspectives, 27(3), 3-20. https://doi.org/10.1257/jep.27.3.3

Ayentimi, D. T., Burgess, J., \& Brown, K. (2018). A conceptual framework for international human resource management research in developing economies. Asia Pacific Journal of Human Resources, (August 2016), 216-237. https://doi.org/10.1111/1744-7941.12132 
INTERNATIONAL JOURNAL OF ACADEMIC RESEARCH IN BUSINESS AND SOCIAL SCIENCES Vol. 10, No. 6, June, 2020, E-ISSN: 2222-6990 @ 2020 HRMARS

Barnett, M. L., Henriques, I., \& Husted, B. W. (2020). Beyond Good Intentions: Designing CSR Initiatives for Greater Social Impact. Journal of Management, O(December), 162-175. https://doi.org/10.1177/0149206319900539

Bartlett, G., Longo, C., Puzhko, S., Gagnon, J., \& Rahimzadeh, V. (2018). Deliberative stakeholder consultations: Creating insights into effective practice-change in family medicine. Family Practice, 35(6), 749-752. https://doi.org/10.1093/fampra/cmy056

Betts, T. K., Setterstrom, A. J., Pearson, J. M., \& Totty, S. (2014). Explaining cyberloafing through a theoretical integration of theory of interpersonal behavior and theory of organizational justice. Journal of Organizational and End User Computing, 26(4), 23-42. https://doi.org/10.4018/joeuc.2014100102

Bhatti, M. A. (2014). Human resource management factors and service recovery performance in Malaysian life insurance industry Exploring the moderating effects of. Research Gate, O(August), 1-30. https://doi.org/10.1108/EJTD-07-2013-0078

Branine, M., \& Pollard, D. (2010). Human resource management with Islamic management principles: A dialectic for a reverse diffusion in management. Personnel Review, 39(6), 712727. https://doi.org/10.1108/00483481011075576

Budhwar, P., \& Pereira, V. (2019). The state of HRM in the Middle East : Challenges and future research agenda. Asia Pac J Manag, 0(7), 905-933.

Burke-smalley, L. A., \& Hutchins, H. M. (2014). Training Transfer : An Integrative Literature Review Training Transfer : An Integrative Literature Review. Research Gate, 6(3), 1-35. https://doi.org/10.1177/1534484307303035

Chowdhury, A. H., Hoque, N., \& Mawla, M. M. (2012). Human Resource Management from Islamic Perspective. Bangladesh Journal of Islamic Thought, 7(10), 19-36.

Zoli, C. M. C. B., and H. K. (2017). Justice in Post-Conflict Settings : Islamic Law and Muslim Communities as Stakeholders in Transition. Utrecht Journal of International and European Law, 33(85), 38-61.

Cropanzano, R., Byrne, Z. S., Bobocel, D. R., \& Rupp, D. E. (2001). Moral virtues, fairness heuristics, social entities, and other denizens of organizational justice. Journal of Vocational Behavior, 58(2), 164-209. https://doi.org/10.1006/jvbe.2001.1791

Crowley-henry, M., \& Ariss, A. Al. (2018). Talent management of skilled migrants : propositions and an agenda for future research Talent management of skilled migrants : propositions. The International Journal of Human Resource Management, 29(13), 2054-2079. https://doi.org/10.1080/09585192.2016.1262889

Cruz, A. P. S. (2013). the Guiding Principles of Faith: Sincerity, Honesty and Good Will in Islam. Journal of Chemical Information and Modeling, 53(9), 1689-1699. https://doi.org/10.1017/CBO9781107415324.004

Doktoralina, C. M. (2016). Relationship Between Extrinsic Motivation and Compliance To Pay Income Zakat Among Academic People In Indonesia: Conceptual Framework Analysis. The 9 Th International Workshop of Development of Islam (WAPI-9), O(February), 15-19.

Dysvik, A. (2010). Exploring alternative relationships between perceived investment in employee development, perceived supervisor support and employee outcomes. HUMAN RESOURCE MANAGEMENT JOURNAL, 20(2), 138-156. https://doi.org/10.1111/j.17488583.2009.00120.x

Ebrahimi, M., \& Yusoff, K. (2017). Islamic Identity, Ethical Principles and Human Values. European 
INTERNATIONAL JOURNAL OF ACADEMIC RESEARCH IN BUSINESS AND SOCIAL SCIENCES Vol. 10, No. 6, June, 2020, E-ISSN: 2222-6990 @ 2020 HRMARS

Journal of Multidisciplinary Studies, 6(1), 325. https://doi.org/10.26417/ejms.v6i1.p325-336

Erdil, M. (2016). M. Fethullah Gülen's understanding of sunnah. ACU Research Bank, 0(7), 1-335.

Erihadiana, M. (2019). The Implementation of Islamic Local Content in Building Character Education at Junior High Shcool Al Amanah Bandung. Jurnal Pendidikan Islam, 4(2), 41-50. https://doi.org/10.15575/jpi.v4i2.3812

Fischer, R., \& Smith, P. B. (2006). Who cares about justice? The moderating effect of values on the link between organisational justice and work behaviour. Applied Psychology, 55(4), 541-562. https://doi.org/10.1111/j.1464-0597.2006.00243.x

Gadelrab, H. F., Alkhadher, O., Aldhafri, S., Almoshawah, S., Khatatba, Y., El Abiddine, F. Z., ... Slimene, S. (2020). Organizational Justice in Arab Countries: Investigation of the Measurement and Structural Invariance. Cross-Cultural Research, 54(1), 3-27. https://doi.org/10.1177/1069397118815099

Ghernaout, D. (2017). Environmental Principles in the Holy Koran and the Sayings of the Prophet Muhammad. American Journal of Environmental Protection, 6(3), 75-79. https://doi.org/10.11648/j.ajep.20170603.13

Glaister, A. J., Tatoglu, E., \& Karacay, G. (2018). HRM and performance - The role of talent management as a transmission mechanism in an emerging market context. Human Resource Management Journal, O(July 2017), 148-166. https://doi.org/10.1111/1748-8583.12170

Greenberg, J. (1987). A Taxonomy of Organizational Justice Theories. Academy of Management Review, 12(1), 9-22. https://doi.org/10.5465/amr.1987.4306437

Haji-Othman, Y., \& Fisol, W. N. M. (2017). Islamic Religiosity, Attitude and Moral Obligation on Intention of Income Zakat Compliance: Evidence from Public Educators in Kedah. Journal of Academic Research in Business ..., 7(2), 726-737. https://doi.org/10.6007/IJARBSS/v7$\mathrm{i} 2 / 2680$

Hashim, J. (2009). Islamic revival in human resource Islamic management practices among selected Islamic organisations in Malaysia. Islamic Revival in HRM Practices, 2(3), 251-267. https://doi.org/10.1108/17538390910986362

Hashim, J. (2010a). Human resource management practices on organisational commitment: The Islamic perspective. Personnel Review, 39(6), 785-799. https://doi.org/10.1108/00483481011075611

Hashim, J. (2010b). Human resource management practices on organisational commitment The Islamic perspective. Emerald Group Publishing Limited, 39(6), 785-799. https://doi.org/10.1108/00483481011075611

Hashim, M. (2012). Islamic Perception of Business Ethics and the Impact of Secular Thoughts on Islamic Business Ethics. International Journal of Academic Research in Business and Social Sciences, 2(3), 98-120.

Ibrahim, H. D., Omar, N. H. H. (2018). Critical Financial Analysis of Islamic Bank in the Philippines: Case Study of Amanah Islamic Bank Hasmiene Diocolano Ibrahim (Corresponding author) Department of Environment and Natural Resources Autonomous Region in Muslim Mindanao, ORG Compound City. This Journal Is a Member of and Subscribes to the Principles of the Committee on Publication Ethics (COPE), O(January), 1-12.

Hazween, F., Amanah, B., Ridzuan, A. R., Ain, N., Binti, A., Studies, M., ... Melaka, M. (2019). eJournal of Media \& Society The trustworthy of Halal Logo on imported food in Malaysia. EJournal of Media \& Society, 3(July), 1-13. 
INTERNATIONAL JOURNAL OF ACADEMIC RESEARCH IN BUSINESS AND SOCIAL SCIENCES

Vol. 10, No. 6, June, 2020, E-ISSN: 2222-6990 @ 2020 HRMARS

Helen McLaren 1, and N. Q. 2. (2020). Good Intentions, Some Not So Good Outcomes. MDPI, O(12), 1-11.

Hunter, S. T., Shortland, N. D., Crayne, M. P., Ligon, G. S., \& Samuel, T. (2017). Recruitment and Selection in Violent Extremist Organizations : Exploring What Industrial and Organizational Psychology Might Contribute. American Psychological Association, 72(3), 242-254.

Isgandarova, N. (2019). Muraqaba as a Mindfulness-Based Therapy in Islamic Psychotherapy. Journal of Religion and Health, 58(4), 1146-1160. https://doi.org/10.1007/s10943-0180695-y

Islam, M. S., \& Samsudin, S. (2018). Interpretations of Al-amanah Among Muslim Scholars and Its Role in Establishing Peace in Society . Social Change, 48(3), 437-450. https://doi.org/10.1177/0049085718781689

Jung, H. J., \& Ali, M. (2017). Corporate social responsibility, organizational justice and positive employee attitudes: In the context of Korean employment relations. Sustainability (Switzerland), 9(11), 1-24. https://doi.org/10.3390/su9111992

Jusoh, W. N. H. W., \& Ibrahim, U. (2018). The Significance of Corporate Social Responsibility Disclosure to Islamic Banks in Malaysia : An Islamic View. Journal of Islamic Finance, 7(1), 18. https://doi.org/10.12816/0051130

Kadhim, A. S., Ahmad, S. B., \& Ahmad, M. (2018). Islamic Ethics : The Attributes of Al-Ihsan in the Quran and Its Effects on Muslim Morality Islamic Ethics : The Attributes of Al-Ihsan in the Quran and Its Effects on Muslim Morality. Research Gate, 8(January), 1-7.

Kamil, N. M. , Sulaiman, M., Osman-Gani, A. M. , \& Ahmad, K. (2010). Implications of Piety (Taqwa) on Organizational Citizenship Behavior (OCB) from Islamic Perspective: A Study of Professionals in Southeast Asia. 9th International Conference of the Academy of HRD (Asia Chapter), O(1), 166-181.

Kamrujjaman, M., Al Mamun, M. A., \& Akter, S. (2014). Human Resource Management Practices in Bangladesh : An Empirical Study on Employees' Satisfaction at Private Commercial Banks. World Vision, 8(1), 132-141.

Khan, B., Farooq, A., \& Hussain, Z. (2010). Human resource management : an Islamic perspective. Asia-Pacific Journal of Business Administration, 2(1), 17-34. https://doi.org/10.1108/17574321011037558

Khan, K., Abbas, M., Gul, A., \& Raja, U. (2013). Organizational Justice and Job Outcomes: Moderating Role of Islamic Work Ethic. Journal of Business Ethics, 126(2), 235-246. https://doi.org/10.1007/s10551-013-1937-2

Shahid, K., Arshad, M. A. K. K. (2018). Self-Development Through Soul Management: Context Of Islamic Spritual Intelligence. Research Journal Of Commerce Education \& Management Sciences, 1(1), 1-13.

Khattab, N. (2016). The Ethno-Religious Wage Gap within the British Salariat Class: How Severe is the Penalty? Sociology, 50(4), 813-824. https://doi.org/10.1177/0038038515575865

Kim, W., \& Park, J. (2017). Examining structural relationships between work engagement, organizational procedural justice, knowledge sharing, and innovative work behavior for sustainable organizations. Sustainability (Switzerland), 9(2), 1-16. https://doi.org/10.3390/su9020205

Loi, R., Hang-yue, N., \& Foley, S. (2006). Linking employees' justice perceptions to organizational commitment and intention to leave: The mediating role of perceived organizational support. 
INTERNATIONAL JOURNAL OF ACADEMIC RESEARCH IN BUSINESS AND SOCIAL SCIENCES

Vol. 10, No. 6, June, 2020, E-ISSN: 2222-6990 @ 2020 HRMARS

Journal of Occupational and Organizational Psychology, 79(1), 101-120.

https://doi.org/10.1348/096317905X39657

Majeed, M. T., \& Zanib. (2016). Humanomics Article information : Humanomics, 32(1), 19-32.

Majid, N. A., Zainol, F. A., Daud, W. N. W., Rashid, N., \& Afthanorhan, A. (2018). Entrepreneurial Intention from the Islamic Perspective: A Holistic Approach. International Journal of Academic Research in Business and Social Sciences, 8(12), 1-15. https://doi.org/10.6007/ijarbss/v8-i12/5077

Yunus, M. I. Bin. (2018). Good Governance According to Islamic Perspective. Fiat Justisia, 11(3), 200-230. https://doi.org/10.25041/fiatjustisia.v11no1.696

Mohamed-Saleem, A. (2016). Understanding Principles and Community Practices Related to NonViolence and Conflict Resolution from an Islamic Tradition. JIABU, 9(1), 57-69.

Mohamed, S. B., Sultan, U., Abidin, Z., Shaladdin, M., \& Abdullah, A. H. (2014). Strengthening of Islamic Quality Management Practices Through Culture of Perfection ( Itqan ) and the Value of Courtesy ( Ihsan ) Toward the Business Perfomance of Muslim Entrepreneur Strengthening of Islamic Quality Management Practices Through Culture o. Research Gate, 8(4), 237-243.

Mohd. Sidek, H., Ismail, S., Said, M. N. S., Behak, F. P., Baharun, H., Ramli, S., ... Ali, M. S. (2017). an Analysis of Taqwa in the Holy Quran: Surah Al- Baqarah. IJASOS-International E-Journal of Advances in Social Sciences, 111(July), 401-406. https://doi.org/10.18769/ijasos.336598

Monjur, M. (2015). Concept of Leadership and the Quality of a good leader in Islam Introduction : Leadership : Research Gate, O(November), p472-499. https://doi.org/10.13140/RG.2.1.2452.6800

Mushtaq, M., \& Khan, J. (2018). Paradigm Shift from Conventional to Islamic Banking System: A Case of the Conversion of Taqwa Islamic Banking in Pakistan. Global Regional Review, III(I), 321-332. https://doi.org/10.31703/grr.2018(iii-i).23

Mutasim, N., Ab, N., Alias, M. A., Shahid, S., Hamid, M. A., \& Alam, S. S. (2013). Relationship between Islamic Human Resource Management ( IHRM ) practices and trust : An empirical study Practical im. Journal of Industrial Engineering and Management, 6(4), 1105-1123.

Mutasim, N., Ab, N., Shahid, S., \& Alam, S. S. (2011). Relationship Between Islamic HRM Practices and Employee Commitment : an Empirical Study of Islamic Banks in Bangladesh. Journal of Applied Sciences Research, 7(8), 1269-1278.

Nuriman, N., \& Fauzan, F. (2017). The Influence of Islamic Moral Values on the Students' Behavior in Aceh. Dinamika Ilmu, 17(2), 275-290. https://doi.org/10.21093/di.v17i2.835

Ogunbado, A., \& Ahmed, U. (2019). Islamic Ethics of Management: Principles, Standards and Practices. Research Gate, Vol. 1(February), 43-76.

Quttainah, M. A., \& Almutairi, A. R. (2017). Corporate ethics: evidence from Islamic banks. Journal of Management and Governance, 21(4), 815-840. https://doi.org/10.1007/s10997-0169360-6

Rahman, F. N. (2010). Islamic Approaches to Human Resource Management in Organizations. International Journal of Development Research, 0(October), 1-6.

Rahman, M. (2016). An Islamic Perspective of Organizational Controls and Performance Evaluation. Research Gate, O(September), 1-17.

Rokhman, W., \& Hassan, A. (2012). The effect of Islamic work ethic on organisational justice. African Journal of Business Ethics, 6(1), 25. https://doi.org/10.4103/1817-7417.104699 
INTERNATIONAL JOURNAL OF ACADEMIC RESEARCH IN BUSINESS AND SOCIAL SCIENCES

Vol. 10, No. 6, June, 2020, E-ISSN: 2222-6990 @ 2020 HRMARS

Rumbley, L., Van't Land, H., \& Becker, J. (2018). Higher Education Leadership Training: Global Maps and Gaps. International Higher Education, 0(93), 4-6.

https://doi.org/10.6017/ihe.0.93.10415

Rusdi, A., \& Indonesia, U. I. (2017). Patience in Islamic Psychology and Its Measurement. Research Gate, 0 (December), 1-14.

Ruzicka, J. (2018). Behind the veil of good intentions: Power analysis of the nuclear nonproliferation regime. International Politics, 55(3-4), 369-385. https://doi.org/10.1057/s41311-017-0086-0

Sa'ari, C. Z., \& Harun, N. U. (2018). Self-Esteem in Shaping Youth Personality from Islamic PsychoSpiritual Perspective. Journal of Usuluddin, 46(1), 71-86. https://doi.org/10.22452/usuluddin.vol46no1.4

Sadeghi-boroujerdi, E. (2006). Mostafa Malekian: Spirituality, Siyasat-Zadegi and (A)political SelfImprovement. DOmES, 23(2), 279-311.

Sadiq, M., Mokhtar, M., Sadiq, M., \& Mokhtar, M. (2018). Kaizen from Islamic Perspective : A Review Paper Kaizen from Islamic Perspective : A Review Paper. IJARBSS, 8(5), 898-910. https://doi.org/10.6007/IJARBSS/v8-i5/4227

Salleh, M. F. (2015). Islam the system of life. Research, 1(1), 1-10. https://doi.org/10.13140/RG.2.1.1403.0801

Sarfraz, M., Qun, W., Abdullah, M. I., \& Alvi, A. T. (2018). Employees' perception of Corporate Social Responsibility impact on employee outcomes: Mediating role of organizational justice for Small and Medium Enterprises (SMEs). Sustainability (Switzerland), 10(7), 1-19. https://doi.org/10.3390/su10072429

Saritoprak, S. N., Exline, J. J., \& Stauner, N. (2018). Spiritual Jihad among U . S . Muslims : Preliminary and Growth. MDPI, O(9), 1-22. https://doi.org/10.3390/rel9050158

Sheikh, M., \& Bhatti, M. (2017). International Journal of Multidisciplinary and Current Research Impact of Islamic Management Principles on Organizations Regardless of Religion. J. of Multidisciplinary and Current Research, 5(April), 268-273.

Sulaiman, R. (2018). Not opted-out Rahizah Sulaiman *. Research Gate, O(December), 1-27.

Tarique, I., \& Caligiuri, P. (2009). The role of cross-cultural absorptive capacity in the effectiveness of in-country cross-cultural training. International Journal of Training and Developmen, $\mathrm{O}(0)$, 148-165.

Uddin, M. R., Iqbal, M. J., \& Hoque, N. (2014). Compensation Management from Islamic Perspective. European Journal of Business and Management, 6(17), 37-43.

Umphress, E. E., Labianca, G., Brass, D. J., Kass, E., \& Scholten, L. (2003). The Role of Instrumental and Expressive Social Ties in Employees' Perceptions of Organizational Justice. Organization Science, 14(6), 1-18. https://doi.org/10.1287/orsc.14.6.738.24865

Wang, X., \& Wart, M. W. (2007). When Public Participation in Administration Leads to Trust: An Empirical Assessment of Managers' Perceptions. XiaoHu Wang, 0(3), 1-14. 